\title{
Measures of farm business success: liquidity versus profitability
}

\author{
N. M. SHADBOLT ${ }^{1}$ and J.W.M GARDNER ${ }^{2}$ \\ ${ }^{I}$ Institute of Food, Nutrition and Human Health, Massey University, Palmerston North \\ ${ }^{2}$ Institute of Natural Resources, Massey University, Palmerston North
}

N.M.Shadbolt@massey.ac.nz

\begin{abstract}
Investing in farmland is fraught with conflicting signals. While investing in land may generally be profitable it is seldom, if ever, feasible on a cash flow basis. The non-depreciable nature of land and longterm capital gains are incompatible with the capital recovery terms sought by investors and lenders. The literature on this subject tends to focus on either the returns (profitability) or the cash flow (feasibility) but not on both simultaneously. Too frequently rural professionals use the terms profitability and cashflow (liquidity) interchangeably.

This paper presents a range of profitability measures and distinguishes between them and commonly used liquidity measures. The profitability measures include activity based costing which involves full economic costing and the entrepreneur's profit/loss is the difference between cost of production and market price.
\end{abstract}

It is concluded that a number of measures are relevant to farm businesses but these should not be used in isolation. The critical importance of liquidity measures is reinforced but their use as profitability measures is criticised.

Keywords: business success, farming business, liquidity, profitability, property business

\section{Introduction}

Considering only annual profitability measures for a long-term investment such as farmland can be misleading due to the volatility of annual profit and the nature of farming returns. Oltmans (2001) concluded that while investing in land may generally be profitable it is seldom, if ever, feasible on a cash flow basis. He argued that the non-depreciable nature of land and long-term capital gains are incompatible with the capital recovery terms sought by investors and lenders.

If these are the facts about investing in land why do people continue to buy land and what makes it worthwhile for them? Or do we agree with those rural professionals who state that farmers are not clear in their investment decisions; they are too influenced by 'lifestyle' factors to make rational decisions? And are non-farmer landowners similarly afflicted with emotional bias in their investment decisions? Are the rural professional's definitions of lifestyle and rational decisions correct or relevant?

To assist in this debate it is helpful to split the farm into two businesses that are often, but not necessarily, linked - the property business, where success is measured by changes in asset values over time and driven by smart purchase and sale decisions, and the farming business, where success reflects effective, efficient and sustainable operation of the resource base. Historically "property" has out-performed "farming" although its returns have been three times more volatile than farming returns (Nartea \& Basanta 1998; Brown 1999).

The problem in measuring the aggregate performance of the two businesses is that success in one (e.g. capital gain) can cause a measure of failure in the other (e.g. reduced return on assets) when, in fact, both businesses could be performing well. This is exacerbated because returns to land are a principal determinant of farmland price (Cloughley \& Journeux 1992). Land produces current earnings and is a vehicle for accumulating wealth thereby delivering to two common farming goals (Oltmans 2001). There are other factors that influence land value including interest rates, exchange rates, profitability of alternative investments, supply and demand, opportunities for change in land use and global security. In some countries capital gains tax curbs land value increases, in Australia for example farmland values have not increased at the same rate as in New Zealand (Malcolm pers. comm.).

Nartea \& Basanta (1998) and Brown (1999) have shown that the returns (both property and farming) from the farm business fluctuate significantly and differently to those from stocks and bonds. Nartea \& Pellegrino (1997) determined that $68 \%$ of farmland risk could be eliminated through effective diversification; a diverse portfolio of investments (stocks, bonds and farmland) reduced risk to a third of that from farmland alone. Oltmans (2001) referred to recent studies showing total rates of return to farmland compared favourably with non-farm assets when adjusted for risk. He also observed that literature on investing tends to focus on either the returns (profitability) or the cash flow (feasibility) rather than jointly. 


\section{Profitability}

While farmers are often criticized for accepting low returns from their farming business and relying heavily on those from property, they are operating a business in which few assets depreciate. The opportunity cost of their capital is a combination of the returns from both the farming and property businesses (many expect at the very least an inflation proof investment).
Too frequently rural professionals use the terms profit and cash surplus (liquidity) interchangeably. As identified above the overall profitability of a farm investment is the sum of its farming and property business. The farming business delivers primarily a cash result; the property business does not. 'Asset rich, cash poor' is commonly used to describe farming, suggesting liquidity difficulties that Oltmans (2001) described as persistent cash flow problems. The

Figure 1 Profitability of the weighted average all classes farm from the New Zealand Sheep and Beef Farm Survey 2000/01 (The Economic Service 2001).

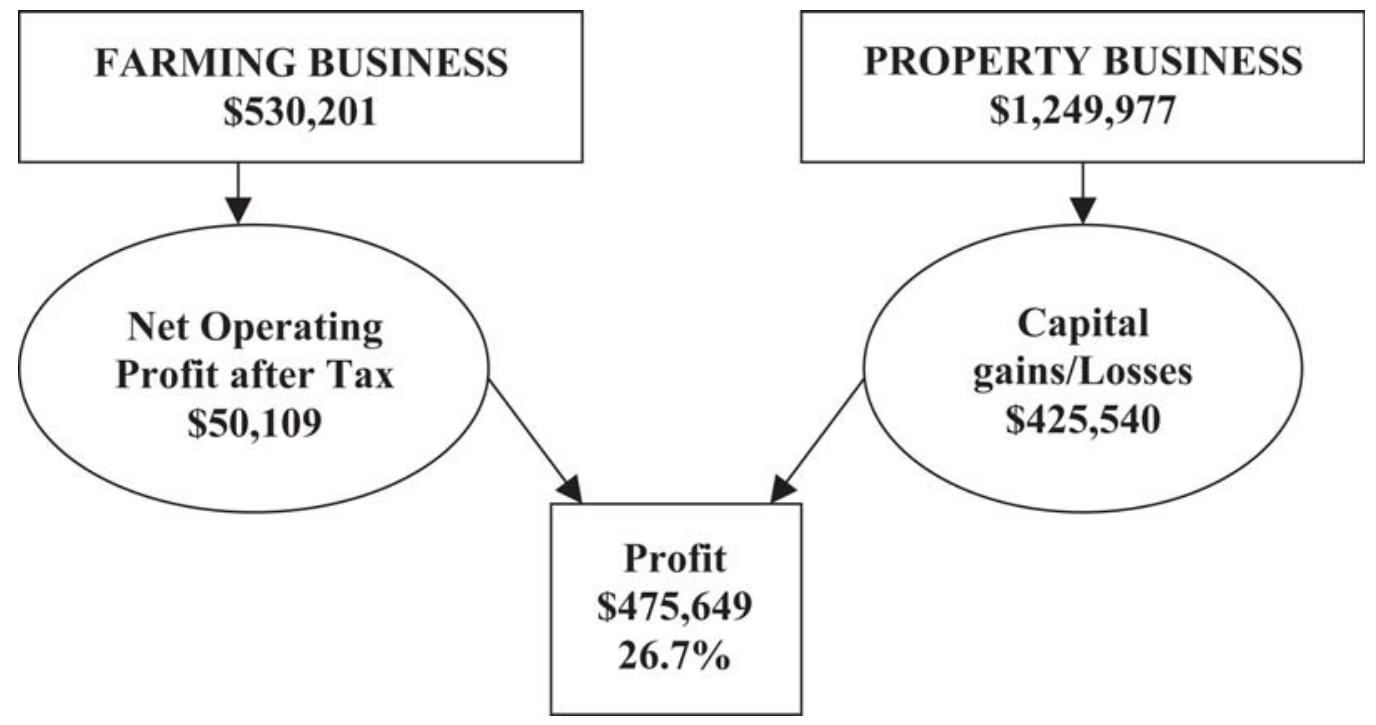

Figure 2 Profitability of the weighted average all classes farm from the New Zealand Sheep and Beef Farm Survey 1999/00 (The Economic Service 2000).

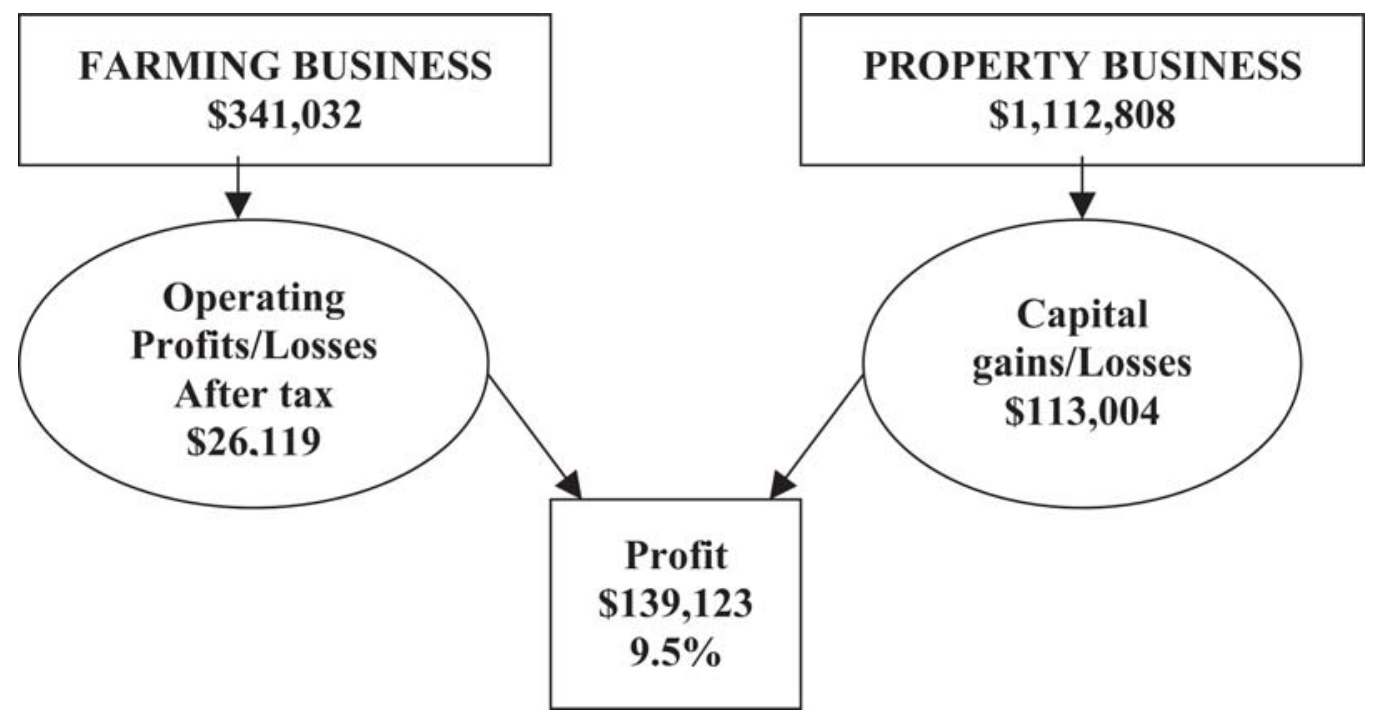


problem inherent in a land investment is therefore usually that of liquidity not profitability.

Overall profitability is the sum of the returns from the farming business, the operating profit after tax, and capital gains or losses from the property business. The returns for 2000/2001 using the weighted average all classes data from the New Zealand Sheep and Beef Farm Survey 2000/01 (The Economic Service 2001) are shown in Figure 1. The capital gain increases the return for this business nine-fold; a $26.7 \%$ return was generated from total opening assets valued at $\$ 1780$ 201 (land and buildings of $\$ 1.25 \mathrm{~m}$ plus livestock, plant and machinery of $\$ 530201$ ). In the previous year the capital gain more than tripled the return for this business; a 9.5\% return was generated from total assets valued at $\$ 1453840$ (Figure 2). It must be remembered that capital gains are not easily assessed and are unrealised until the farm is sold.

The return on assets after tax (net operating profits after tax / opening assets) for this farm in 2000/2001 and $1999 / 2000$ was $2.8 \%$ and $2.0 \%$ respectively. Using that measure alone as an indication of returns and as a guide to investments who would have decided not to buy land in 1999 or 2000 and miss out on 9.5$26.7 \%$ and subsequent returns?

A recently developed and now frequently quoted driver of wealth creation is EVAã or Economic Value Added. This is the difference between the profits generated by a business and its cost of capital.

The above methods for measuring profitability take into account neither the timeframe of the investment, nor the volatility of property business returns. In 1996/ 97 and 1997/98, for example, farmland values fell (Dexcel 2001; The Economic Service 2002).

Oltmans (2001) used a capital budgeting framework to take account of the time value of money. Oltmans' (2001) method is further explored by Shadbolt \& Gardner (2002). The farm, outlined in Appendix One, has an average operating profit (economic farm surplus) of \$264/ha and a $6 \%$ return on assets (RoA). In a good year the profit is $\$ 462 /$ ha, $10.5 \%$ RoA, and in a poor year $\$ 99 / \mathrm{ha}, 2.3 \%$ RoA. In an average year the $6 \%$ return on assets would not meet funding costs of $8 \%$; there would be a $2 \%$ shortfall $(\$ 88 / \mathrm{ha} / \mathrm{yr})$ if the farm was totally funded at that cost. This would quickly lead to a liquidity crisis unless alternative arrangements were found. One common, often short-term response, is not rewarding the family for the market value of their labour and management. Another arrangement is termed 'passive' equity where all or part of the equity receives no cash return. The first indicator of a liquidity crisis would be erosion in working capital (a cash deficit). The mix of assets will determine the ability a business has to respond to such crises; those with liquid assets (cash reserves) being in the stronger position. Debt may be raised to address the crisis but the scope to do this over time will fall as the ratio of debt to equity increases (credit reserves are depleted).

Shadbolt \& Gardner (2002) calculated that an increase of just under $4 \%$ per annum on asset values from the property business in their example farm would provide a combined average return of $8 \%$ over the 15 years. In this instance equity holders would need patience and be reconciled to this investment being a growth (equity generation) rather than an income (cash generation) investment. This has been well understood by many successful farming families over the years. Long-term investments, often spanning 2-3 generations must be able to tolerate short-term variation in returns.

The emphasis placed on operating profit by farmers and consultants has not been misplaced because as profits increase so is liquidity enhanced. Farm investments become income as well as growth investments.

\section{Liquidity}

Martin \& Woodford (2003) explained how the liquidity crises resulting from the Great Depression created the need for farm management professionals who could prepare annual cash budgets and determine the level of debt for financial viability. The emphasis on liquidity in farm management training has not diminished; the expectation now as then is that professionals can prepare 'whole farm' cash forecast and cash flow budgets based on a firm understanding of the physical and financial capability of a farm and the farm policy.

The focus of a cash forecast budget is on the expected cash surplus (or deficit). This is the key measure of liquidity and is the change in working capital for the business from the start of the financial year to the end. Persistent cash flow problems as described by Oltmans (2001) will result in an erosion of working capital over time so it is a measure both farmer and financier monitor. There is usually a requirement by both parties that the cash forecast budget for any proposed plan be expected to generate an acceptable cash surplus (or deficit). The focus of the cash flow budget is also on liquidity. Where the timing of cash inflows and outflows differ, there is a liquidity issue and either cash reserves and/or borrowing facility are required. Liquid reserves are also required to meet uncertain cash flows.

For the example farm quoted by Shadbolt \& Gardner (2002) business debt must be structured to ensure viability. The profit of $\$ 264 /$ ha, which includes 
a reward for family labour, must not exceed the cash costs of interest and principal, capital expenditure, taxation and, if required, any additional drawings. As the return on assets is less than the cost of funds, either no debt or a combination of debt and 'passive' equity is required. At a $20 \%$ debt level (the 2001 national average (The Economic Service 2001)) and assuming all equity is 'passive', the cash surplus is $\$ 80 / \mathrm{ha}$.

Returns for this farm can range between $\$ 462$ and $\$ 99 /$ ha. Using @RISK to simulate returns within this range with a $20 \%$ debt level there is a $5 \%$ probability of a cash deficit. If the debt level is $30 \%$, the probability becomes $18 \%$, while at $40 \%$ debt it is $39 \%$. The level of debt the farm adopts will reflect farmer and banker expectations and their respective attitudes to risk. Cash surpluses are therefore driven by the amount of debt, 'passive' equity and family lifestyle expectations as well as the level of profit and should not be mistaken for profitability.

\section{Cost of production}

The cost of production is the sum of both cash and non-cash expenses and includes both operational expenses that occur irrespective of how the business is funded or owned, and funding costs reflecting business ownership and financing. The difference between cost of production and returns is termed the entrepreneur's profit (IFCN 2002) and is akin to achieving a positive EVAã for the business. The greater the entrepreneur's profit the stronger the business is positioned for future growth and wealth creation. It also provides the business with a risk 'buffer' against adverse climate or markets.

\section{Costs per unit of output}

While costs are often expressed on a per enterprise, per hectare or per stock unit basis the most relevant measure is cost per unit of output as this can be readily compared against the returns per unit of output to determine profitability. Allocating variable operating costs to enterprises is simple but there is significant debate in accounting literature on allocating fixed operating and funding costs to different outputs. Using an allocating method called Activity Based Costing (ABC), Montes de Oca \& Shadbolt (2000) allocated fixed costs to pasture consumed as the main overhead cost in pastoral farm enterprises is pasture dry matter production (DM). This method is illustrated for the example farm (Appendix I) and results in costs of production of liveweight of $\$ 1.36 / \mathrm{kg}$ and $\$ 1.08 / \mathrm{kg}$, which can be easily compared with the prevailing market prices offered for store lambs and weaner cattle respectively. Factors such as stocking rates, lambing and calving percentages, death rates, growth rates, variable and fixed costs and income from by-products all impact on cost calculations. The impact of variability in pasture production, simulated using@RISK, generated a range in costs of production (at the 5\% and $95 \%$ confidence limits) of $\$ 1.25-1.50 / \mathrm{kg}$ for lamb and $\$ 1-1.20 / \mathrm{kg}$ for beef.

\section{Conclusion}

A number of financial measures are relevant to a farm business. Using one or two measures in isolation is not recommended. Liquidity was and continues to be of critical importance to farm businesses. Alternative investments should be assessed for their feasibility and their profitability. However liquidity measures cannot be used to calculate efficiency as they only include cash costs. Full economic costing is necessary in both profitability and cost of production estimates if a relevant comparison of alternatives is to be made. While profitability of a farm investment is the sum of its farming and property businesses not all profitability measures adequately recognise that one business is delivering primarily a cash result and the other is not. The problem inherent in a land investment is that of liquidity not profitability so a variety of methods are employed to ensure viability such as low levels of debt, cash reserves, passive equity funds and not rewarding family labour with cash. Although many successful farming families understand and practise these methods it does create an entry barrier to farming to those unwilling or unable to practise them. It also reduces our international competitiveness if it limits capital investment rates. If higher levels of debt are necessary then higher levels of operating profit (EFS) are essential to ensure business viability. The most successful outcome is one in which the quality of management of the investment enables it to become both a cash and an equity generator, i.e. both an income and a growth investment.

\section{REFERENCES}

Brown, B. 1999 How do farm returns compare with returns from stocks or bonds? Proceedings of the International Farm Management Congress: 12 (on CD).

Cloughley, B; Journeux, P. 1992. An investment perspective on the productive value of farmland. Internal MAF Policy Document, Ministry of Agriculture and Fisheries, Wellington.

Dexcel 2001. Economic Survey of Dairy Farmers 1999/2000. Dexcel, Hamilton.

IFCN 2001. The Dairy Report 2001. International Farm Comparison Network. Cited from www.ifcn.org. 
Martin, S; Woodford, K. 2003 The farm management profession in New Zealand: where are our roots? Proceedings of the Annual Conference of the Australian Agricultural and Resource Economics Society 47: (in press).

Montes De Oca, O; Shadbolt, N.M. 2000. Vertical co-ordination in the New Zealand lamb supply chain: Methods by which to better assess risk return profiles. Fourth International Conference on Chain Management in Agribusiness and the Food Industry: 303-312.

Nartea, G.V; Pellegrino, J.M. 1997. Risk-return characteristics of farmland and their implications for land value. Proceedings of the New Zealand Society of Farm Management Conference: 165 172.

Nartea, G.V; Basanta, R.D. 1998. Diversifiable and non-diversifiable risk in New Zealand dairy farming. Proceedings of the New Zealand Society of Farm Management Conference: 172-182.

Oltmans 2001. Why farmland cannot, will not and should not pay for itself. Journal of the American Society of Farm Managers \& Rural Appraisers: 57-67.

Shadbolt, N. M; Gardner, J. 2002. Investing in farming: Profitability, liquidity, depreciating and appreciating assets. Primary Industry Management 5 (2): 31-33.

The Economic Service, $2000 \&$ 2001. Sheep and Beef Farm Survey 1999-2000, 2000/2001. The Economic Service Publication Nos. G2201 and G2235, Wellington.

The Economic Service 2002. Annual Review of the New Zealand Sheep and Beef Industry 2001-02. The Economic Service Publication No. G2227, Wellington.

Appendix 1: Cost of production per unit of output for a sheep and beef cattle farm.

The farm is 420 ha and runs 3000 ewes and 100 breeding cows and their replacements. The 'going concern' value of the farm is $\$ 1.848 \mathrm{~m}$ or $\$ 400 /$ stock unit $(\$ 4400 / \mathrm{ha})$. The current returns are:

$\begin{array}{ll}\$ 660 / \text { ha } & \text { gross farm revenue } \\ \$ 396 / \text { ha } & \text { operating expenses } \\ \$ 264 / \text { ha } & \text { operating profit }\end{array}$

This operating profit yields a return on assets of $6 \%$. If the cost of capital is set at $5 \%$ (a rate at which the farm could be leased out) the EVAã for this business is $1 \%$ or $\$ 18480$. The fixed costs of the business are $\$ 536 / \mathrm{ha}$, calculated from $\$ 316 /$ ha of operating expenses ( $\$ 80 /$ ha are variable operating costs) plus $\$ 220 /$ ha of funding costs $(5 \%$ of $\$ 4400 / \mathrm{ha})$. The total costs of production are $\$ 258720$ or $\$ 616 / \mathrm{ha}$.

The total dry matter consumed on the farm is $7233 \mathrm{~kg} \mathrm{DM} / \mathrm{ha}$ of which $86 \%$ is consumed by the sheep enterprise ( $875 \mathrm{~kg} \mathrm{DM} /$ ewe wintered) and $14 \%$ by the cattle (4129 $\mathrm{kg} \mathrm{DM} /$ cow wintered).

The two key products of the farm are lamb and weaner cattle; to simplify this exercise all other products are deemed to be by-products of the lamb or weaner cattle production system. As producing lamb and weaner cattle are the prime purpose of the two systems this is quite a practical approach to take.

The cost of producing each product is the sum of the variable operating costs for each plus their share of the fixed costs less any income from by-products e.g.

Lamb $\$ 33000 \quad$ variable operating costs (shearing, an. health etc)

$\$ 193603$ fixed costs $(86 \%$ of $\$ 536 / \mathrm{ha})$

$(\$ 58300)$ wool income

$(\$ 31800)$ ewe income

$\$ 136503$ total costs of production

The total weight of lamb sold is $45215 \mathrm{~kg}$ equivalent carcass weight so the cost of producing lamb meat is $\$ 3.02 / \mathrm{kg}$ carcass weight $(\$ 136503 / 45215)$. If these lambs were sold store, using a $45 \%$ killing out $\%$, their cost is $\$ 1.36 / \mathrm{kg}$ live weight.

$\$ 600 \quad$ variable operating costs (an.health, freight etc)

$\$ 31517$ fixed costs $(14 \%$ of $\$ 536 / \mathrm{ha})$

$(\$ 16700)$ cow income

$\$ 15417$ total costs of production

The total weight of weaners sold is $14220 \mathrm{~kg}$ live weight so the cost of producing weaner cattle is $\$ 1.08 / \mathrm{kg}$ live weight (\$15417/14220). 